\title{
P150: National action plan for the local production of alcohol-based hand rub for hand hygiene in Senegalese hospitals: situational analysis
}

\author{
F Djiby ${ }^{*}$, N Awa, K Rokhaya, N Babacar
}

From 2nd International Conference on Prevention and Infection Control (ICPIC 2013)

Geneva, Switzerland. 25-28 June 2013

\section{Introduction}

Hand hygiene is an important measure to reduce the risk of infections related to care proceedings. WHO proposes to use alcohol-based hand rubas a strategy for improving hand hygiene in health care settings.

\section{Objectives}

As part oftheimplementation of this strategy, Senegal has initiated anational action planfor the installation ofmanufacturing unitsin hospital pharmaciesand national medicinessuppliers.

\section{Methods}

one of the pilot hospital of the African Patient Safety Partnerships Program supported by the WHO for local production of alcohol-based hand rub is located in In Senegal. The experience of thishospitalis used toestablish apartnership between the Departmentof Health andIntrahealth, USAIDagencyinvolved inthe provision ofqualitycare.The objective ofthis partnership is to strengthen the capacity ofall pharmaciesin thelocal manufacturingof the product. To install these units the Minister of Health signed a circular allowing us to do a situational analysis of pharmacies. The objective was to assess the capabilities of each structure to house a manufacturing unit. The study was funded by Intrahealth. We visited 39 pharmacies.

\section{Results}

In 35 pharmacies we found at least one pharmacist and a pharmacy technician in each structure. The premises

Fann Hospital, Dakar, Senegal were compliant production in $70 \%$ of cases. Only $12 \%$ of pharmacies had equipment.

\section{Conclusion}

These results will be shared with the University Hospitals of Geneva.

\section{Disclosure of interest}

None declared.

Published: 20 June 2013

doi:10.1186/2047-2994-2-S1-P150

Cite this article as: Djiby et al.: P150: National action plan for the local production of alcohol-based hand rub for hand hygiene in Senegalese hospitals: situational analysis. Antimicrobial Resistance and Infection Control 2013 2(Suppl 1):P150

Submit your next manuscript to BioMed Central and take full advantage of:

- Convenient online submission

- Thorough peer review

- No space constraints or color figure charges

- Immediate publication on acceptance

- Inclusion in PubMed, CAS, Scopus and Google Scholar

- Research which is freely available for redistribution

Submit your manuscript at www.biomedcentral.com/submit

(C) 2013 Djiby et al; licensee BioMed Central Ltd. This is an Open Access article distributed under the terms of the Creative Commons 